\title{
Holy Apparition or Hyper-Religiosity: Prevalence of Explanatory Models for Religious and Spiritual Experiences in Patients with Bipolar Disorder and Their Associations with Religiousness
}

\author{
Eva Ouwehand ${ }^{1,2}$ (D) Arjan W. Braam ${ }^{3,4}$. Joannes W. Renes ${ }^{5} \cdot$ \\ Hanneke J. K. Muthert ${ }^{2} \cdot$ Hetty T. Zock ${ }^{2}$
}

Published online: 18 December 2019

(C) The Author(s) 2019

\begin{abstract}
One point that emerges from qualitative research on religion and bipolar disorder (BD) is the problem patients with BD experience in distinguishing between genuine religious experiences and hyper-religiosity. However, clinical practice does not obviously address communication about differences in explanatory models for illness experiences. The aim of the current study is first to estimate the frequencies of different types of explanations (medical versus religious) for experiences perceived as religious and related to BD, second to explore how these types relate to diagnosis and religiousness, and third to explore the frequency of expectation of treatment for religiosity. In total, 196 adult patients at a specialist outpatient center for BD in the Netherlands completed a questionnaire consisting of seven types of explanations for religious experiences and several items on religiousness. Of the participants who had had religious experiences (66\%), 46\% viewed the experiences as 'part of spiritual development' and $42 \%$ as 'both spiritual and pathological,' $31 \%$ reported 'keeping distance from such experiences,' and 15\% viewed them as 'only pathological.' Measures of religiousness were positively associated with 'part of spiritual development' and negatively associated with 'keeping distance from the experiences' and 'only pathological.' Half of the sample viewed religiosity as an important topic in treatment. It can be hypothesized that strength of religiousness may help people to integrate destabilizing experiences related to BD into their spiritual development. However, the ambiguity of strong religious involvement in BD necessitates careful exploration of the subject in clinical practice.
\end{abstract}

Keywords Explanatory models $\cdot$ Religious/spiritual experiences $\cdot$ Bipolar disorder · Religiousness

Eva Ouwehand e.ouwehand@altrecht.nl

Extended author information available on the last page of the article 


\section{Introduction}

\section{Religion and Serious Mental IIIness}

Religion has been reported to play an important role in coping with serious mental illness and can serve as a positive source for recovery for many patients with such a condition (Huguelet et al. 2016; Koenig 2009; Mohr et al. 2012). Religion is likely to sustain hope, a positive sense of self, comfort, meaning of life, enjoyment of life, love, and compassion (Mohr et al. 2006). Furthermore, religion has the capacity to bring together in meaningful coherence existential opposites such as longing and loss, good and evil, or the experienced presence and absence of God in life (Muthert 2007; Zuidgeest 2001).

The role religion plays in relation to mental health can be ambiguous. Increased religiosity can be a sign of religious coping with the symptoms of the illness (Tepper et al. 2001) but might be an indication of the severity of psychosis as well (Abdel Gawad et al. 2017; Getz et al. 2001). Those studies included patients with various diagnoses, not just bipolar disorder (BD). Other studies point to both beneficial and harmful aspects of religion for people with serious mental illness (Koenig 2009; Mohr et al. 2006, Mohr et al. 2012).

Studies that examine the relation between religiousness and BD in particular, are scarce, heterogeneous in design, and show mixed results. They usually investigate relations between religious variables and symptoms of BD (Azorin et al. 2013; Huguelet et al. 2016; Stroppa and Moreira Almeida 2013; Stroppa et al. 2018), measures of well-being or quality of life (Huguelet et al. 2016; Stroppa and Moreira Almeida 2013; Stroppa et al. 2018), or measures of resilience (Mizuno et al. 2018). The current study is focused not on the relation between health outcomes and religious variables in BD but on explanations of particular experiences related to this illness, namely, on experiences that patients perceive as religious or spiritual. From a medical point of view, however, such experiences can be seen as pathological.

\section{Religious Experiences and BD}

In regard to the relation between religious experiences and $\mathrm{BD}$, only two studies are available, as far as the authors know. They were conducted in a predominantly Christian context (Gallemore et al. 1969; Kroll and Sheehan 1989) and described a higher incidence of religious experiences in a group of patients with BD compared to a healthy control group or the general population. In the study of Gallemore and colleagues (1969), the prevalence of a single conversion or salvation experience in 62 persons with a diagnosis of an affective disorder was $52 \%$, against $20 \%$ in the control group with a similar religious background. In four cases, the conversion could be related to mood elation in the structured interview assessing religiousness. In the interview, conversion experiences were interpreted as experiences of a (re)dedication to religious life with a subsequent dedication to a "better life" (Gallemore et al. 1969, p. 485). Jerome Kroll and William Sheehan (1989), reported an incidence of $55 \%$ of 'personal religious experiences' during a manic episode versus $35 \%$ of the general population having 'personal religious experiences' in a subsample $(n=11)$ with $\mathrm{BD}$ of a larger inpatient group.

Ouwehand et al. $(2018,2019 \mathrm{a})$ found that the occurrence of specific self-reported religious or spiritual experiences of persons with $\mathrm{BD}$ did not differ much from frequencies of comparable experiences in the general population. However, these experiences occurred significantly more often in persons with bipolar I disorder (BD I) than with bipolar II disorder (BD II) and were 
reported as occurring more often during mania than not. This study was conducted in a highly secularized context, and the reported types of experiences were not directly comparable with the religious experiences in the American context of the above-mentioned studies.

\section{Clinical Practice: Attention for Various Interpretations}

In clinical practice, a clear demarcation line between genuine religiosity and pathology often cannot be drawn. Distinguishing between hyper-religiosity and genuine spirituality is a concern for patients (Michalak et al. 2006; Ouwehand et al. 2019b). They view hyperreligiosity as excessive religious practice during (hypo) mania, or as being deluded about the truth of their religious experiences during mania (Michalak et al. 2006). This makes them uncertain how to view their own religiosity. The distinction between genuine religiosity and pathology can be problematic for mental health professionals as well (Bassett et al. 2015). The latter are not always adequately equipped to address religious or spiritual problems of patients (Fulford and Sadler 2011) or do not feel at ease with the topic (Huguelet et al. 2011). Possibly, mental health professionals tend to interpret these experiences as related to psychiatric illness. Conflict related to views on illness experiences in BD between professionals and patients can impair treatment (Mitchell and Romans 2003; Stroppa and Moreira-Almeida 2013).

Anthropologically informed studies can shed light on patients' perspectives on illness and recovery. Medical anthropology coined the term 'explanatory models' for mental illness (Kleinman 1988). Explanatory models refer to notions about illness and healing held by the persons who are engaged in the clinical process (patients, family, and medical professionals) as well as to views on illness and health in society (Kleinman 1988). Explanatory models point to how patients perceive, express, and cope with symptoms of their illness and to how practitioners interpret their patients' complaints within their theoretical model of pathology. Medical anthropology holds the view that mental illnesses are not natural 'givens' but stand in a dialectical relationship to personal experience and to prevailing views on illness and treatment in health-care systems in societies (Helman 2001; Kleinman 1988).

The current study intends to explore relationships between various types of explanations, diagnoses, and religious characteristics of participants. These types of explanations are part of the broader concept of explanatory models Kleinman uses. They refer to whether participants evaluated their experiences related to $\mathrm{BD}$ in retrospect as belonging to genuine spirituality, pathology, or both. Religion, seen as part of the larger culture people live in (Geertz 1973; Taves 2009), provides spiritual healing practices, rooted in beliefs, as an alternative healing system to the biomedical approach predominant in mental health care (Hoffer \& Hoenders 2010, Hoffer 2012). In Western, secularized countries, a transformation of religion is taking place (Possamai 2005; Van de Donk and Plum 2006) from institutional, tradition-oriented religion toward new forms of individualized, experience-oriented spirituality. Concepts such as 'well-being,' 'health,' and 'spiritual growth' are inherently part of the cultural vocabulary of these new spiritualities (Possamai 2005).

Religiousness is a multi-dimensional construct that can be measured in various ways. Because of the changing meaning the concepts 'religion' and 'spirituality' have in modern society, recent sociological research often measures people's self-understanding as religious or spiritual in addition to other religious variables such as affiliation and practice (Barker 2008; Bernts and Berghuijs 2016; Possamai 2005; Streib and Hood 2016). We will follow this approach in the current study. This leads to a fourfold typology of groups: neither religious nor spiritual, only religious, only spiritual, and 
religious and spiritual. In Western secularizing societies, an increasing number of people understand themselves as being 'only spiritual.' This group does not identify with any religious tradition and considers the experiential aspect of religion as highly important. However, the group 'religious and spiritual' is the largest both in Europe and in the United States (Barker 2008; Lipka and Gecewicz 2017).

The current study first estimates frequencies of various explanations of religious experiences from the patient's perspective in a Dutch specialized outpatient center for people with BD. Do patients predominantly view such experiences as pathological, religious, or both? Do they have doubts about their significance or do they keep their distance from such experiences? A second aim of the study pertains to the relationship between types of explanations of religious experiences on the one hand and religious variables and diagnoses on the other. Third, treatment expectations are explored. With whom do participants communicate about their religious experiences, and do they find addressing such experiences or religiosity during treatment important or not?

The qualitative study (Ouwehand et al. 2019b) from which the types-of-explanation items in the current study were derived showed a variety of explanations and reactions to religious experiences related to illness episodes. A majority of the respondents endorsed mixed medical and religious explanatory models for their experiences. Spiritual growth or deepening of faith was a theme in 21 of the 34 interviews in the qualitative study. However, uncertainty about the significance of their experiences and keeping distance from religious experiences or from religiosity in general were mentioned as themes during depression as well.

\section{Methods}

\section{Sample}

The study was conducted at a specialist outpatient center for BD of Altrecht Mental Health Care in Utrecht, the Netherlands, in 2017. The study was approved by the Regional Medical Ethical Committee of the University Medical Centre Groningen (METc2014.475) and the Scientific Committee of Altrecht Mental Health Care (2016-40/oz1620).

\section{Research Procedure}

Recruitment was conducted by therapists after patients had first been informed by letter. Written informed consent was provided by all participants. Because of the complexity of the subject, a research assistant supported participants in filling out the questionnaire when necessary, such as when Dutch was not the mother tongue. Included were adults aged 18 to 65 who met the criteria of the Diagnostic and Statistical Manual of Mental Disorders (5th ed.; DSM-5; American Psychiatric Association 2013) for BD II, BD I, or bipolar disorder not otherwise specified, cyclothymia, or schizoaffective disorder bipolar type. The therapist provided the essential diagnostic information pertaining to type and severity of the disorder. The latter was assessed with the Clinical Global Impression for Bipolar Disorder (CGI-BP; Spearing et al. 1997). Patients were not included if they were incapable of filling out the questionnaire (e.g., due to their mental condition). Therapists noted the reasons for nonparticipation when participants did not agree to participate. 


\section{Questionnaire}

A new questionnaire was constructed for the study because no questionnaire with explanatory models related to religious experiences in BD was available. The questionnaire was based on the results of a former qualitative study on religious or spiritual experiences in BD (Ouwehand et al. 2018, 2019b). Included were items on types of explanations of religious experiences related to illness episodes (see Table 3), items on communication and treatment expectations, socio-demographic items, and a range of items to assess religiosity. Results related to the content of religious experiences were published elsewhere (Ouwehand et al. 2018, Ouwehand et al. 2019a); see Appendix 1.

Eleven participants in the previous qualitative study tested the questionnaire for completeness and comprehensibility. A short version of the questionnaire was developed alongside the standard version to include as many patients as possible in cases where there was no specific interest in religion, or people did not have much time. The short version was offered in the current study only in second instance. The aim of the short version was to include the relevant items to estimate the prevalence of different types of religious experiences and their perceived lasting influence (Ouwehand et al. 2019a, b). However, no items about different explanatory models were included. The short version took 5-7 min to fill out and was included in the analysis for the current study only for estimation of communication and treatment expectations.

\section{Variables}

Explanations of religious experiences For the current study, we intended to explore the frequencies of medical, religious, and mixed types of interpretation, uncertainty about how to interpret the experiences, and the reaction of keeping distance from religious experiences or religiosity in general. Seven items were included to assess different types of explanations (see Table 2). They followed the initial remark, 'Looking back at the religious/spiritual experiences I had during mania and depression, I think...' For every question, the response categories were 'yes,' 'no,' or 'I don’t know.'

Communication and treatment expectations The multiple-choice question, 'With whom did you speak about these experiences?' could be answered in the following ways: 'no one,' 'family,' 'friends,' 'peers,' 'psychiatrist,' 'psychologist,' 'nurse or case manager,' 'another professional,' 'alternative therapist,' 'clergy,' 'hospital chaplain.' Variables were computed for each category and were categorized (yes/no) into the groups 'private' for family and friends, 'mental health-care professionals' for the four psychiatric professions, and 'clergy' for clergy members and hospital chaplains. Treatment expectations were assessed with an item on the importance of addressing religious experience in treatment (participants with religious experiences) and an item on the importance of addressing faith/spirituality in general in treatment (total sample), both measured on a 5-point Likert scale ranging from not important at all to very important.

Demographic and diagnostic variables Demographic variables included gender, age, marital status, and level of education. Therapists provided the DSM-5 diagnosis and filled in the scores of the CGI-BP (Spearing et al. 1997). Response categories were $1=$ not ill, $2=$ borderline mentally ill, $3=$ mildly ill, $4=$ moderately ill, $5=$ markedly ill, $6=$ severely ill, $7=$ extremely ill . Severity of the illness is assessed separately for mania, depression, and overall illness. 
Religiosity Several instruments were used to assess religiosity. This was done in order to meet the multidimensionality of the concept religiosity.

Two questions about self-definition as 'religious' or 'spiritual' were used: (a) 'Do you consider yourself a religious person?' (b) 'Do you consider yourself a spiritual person?' Variables were computed to attain a fourfold religious and spiritual (R/S) typology (yes/no): 'neither religious nor spiritual,' 'only religious,' 'only spiritual,' 'religious and spiritual' (Barker 2008; Berghuijs et al. 2013; Casey 2013; Lipka and Gecewicz 2017; Streib and Hood 2016).

The Duke University Religion Index (DUREL) was also used. This is a five-item measure of religious involvement that includes two items on organizational and nonorganizational religious activity and three items on intrinsic religiosity, scaled from 1 (absolutely true) to 5 (absolutely not true). Evidence in support of the reliability and validity of the measure can be found in Koenig and Büssing (2010) but was not available for the Dutch version. Therefore, two existing Dutch translations were back-translated by a certified translator, and this backtranslation was compared by the translator and the researchers (Appendix 2). A variable with the summation scores of the three items of the DUREL on intrinsic religiosity was constructed (Cronbach's alpha 0.85 ) as an indication of religious salience.

The ten-item version of the Brief Religious Coping Questionnaire (RCOPE; Pargament 1999) was included in the relation between religious coping and depression, as in a Dutch study by Braam et al. (2010). It consists of five positive religious coping and five negative religious coping items, scaled from 1 (never) to 4 (very often). As in the study by Braam et al. (2010), in the first item of the negative RCOPE, 'I think about how my life is part of a larger religious force,' 'religious force' was replaced in the translated versions with 'higher allembracing entity' to meet the more secularized Dutch context compared to the American version. Internal consistency of the Dutch version of the positive RCOPE items was sufficient (Cronbach's alpha $=0.87$ ). The consistency of the negative RCOPE was marginal (Cronbach's alpha $=0.61$, but it became acceptable after omitting item 8: 'I try to make sense of the situation and decide what to do without relying on God' (Cronbach's alpha $=0.74$ ). A fouritem negative RCOPE scale was used in the analysis. Although there is some doubt as to whether the brief RCOPE meets the religious profile of individuals in secularized populations (Hvidtjørn et al. 2014; Körver 2013), we used the brief RCOPE because it is used frequently in the literature.

\section{Statistical Procedure}

Descriptive statistics were used for the description of frequencies of the seven types of explanations and items on communication and treatment expectations. A principal component analysis was conducted for the seven types of explanation of religious experiences in illness episodes to get an impression of the possible underlying patterns. Spearman's correlation tests were used to estimate correlations between these seven explanations and religious variables. Because of multiple comparisons, the $\alpha$ level of significance was determined to be .010 . A table presenting the interrelatedness of religious variables is available upon request. Chi-square tests were performed to explore the distribution of the occurrence of various types of explanation across BD I and BD II, excluding participants with the diagnosis bipolar disorder not otherwise specified, cyclothymia, and schizoaffective disorder bipolar type, because of small numbers. Statistical analyses were performed with version 22 of the Statistical Package for the Social Sciences. 


\section{Results}

\section{Patients' General Characteristics}

During the measurement period of the study, the Altrecht Outpatient Department for BD counted 705 patients, of whom 518 patients actually visited the department. The net response rate was 38\%: 196 participants (181 standard version, 15 short version). Reasons for nonresponse were not obtained from all non-responding patients. However, 69 questionnaires were returned that included the reason(s) for not participating in the study (40\% not interested, $16 \%$ keeping distance from such experiences, $15 \%$ other worries, $10 \%$ tired of research, $7 \%$ too busy, $13 \%$ other reasons).

The mean age was 46 (SD 12.8); $60 \%$ were women; $52 \%$ were married or cohabitating; and $70 \%$ had a diagnosis of BD I, 26\% BD II, and 5\% BD not otherwise specified. Those characteristics were similar to characteristics of the total patient population of the Altrecht Outpatient Department for BD (mean age 47, SD 12.4; 56\% women; 73\% BD I, 20\% BD II, and 7\% other diagnoses). Only the marital status was higher in the sample (52\%) than in the total department patient population (37\%). The participants' educational level was high: $53 \%$ had finished university or higher vocational education. This is not assessed in the total patient population of the Altrecht Outpatient Department for BD. For mania, the CGI-BP-value was $\leq 3$ for $99.5 \%$ of the sample; $90 \%$ had values $\leq 3$ for depression; and $79 \%$ had values $\leq 3$ for $\mathrm{BD}$ in general. A score of $\leq 3$ means that the therapist involved estimated the severity of BD as 'not ill' to 'mildly ill.'

\section{Religious Characteristics}

The religious characteristics of the sample are presented in Table 1. Institutional religiousness had decreased among participants since their youth: $29 \%$ were not from a religious home originally, whereas $52 \%$ marked they had no religious affiliation at the time of the study. About a quarter of the sample practiced their faith or spirituality regularly, and $39 \%$ considered faith and/or spirituality (very) important. Religious coping rates were not very high, and negative religious coping scores were even lower than positive religious coping scores.

\section{Frequencies of Various Types of Explanations of Religious Experiences}

Table 2 shows the frequencies of the various types of explanations of R/S experiences of participants who had had such experiences. The explanations 'Such experiences belong to my spiritual development, have deepened my faith' (46\%) and 'both religious/and pathological' (42\%) scored highest.

Principal component analysis with varimax rotation of the seven types of explanations pointed to a two-factor solution, with $54 \%$ of variance explained (see Table 3 ). The first factor (Eigenvalue 2.4) pertained to a view of the experiences as pathological (versus spiritual) related to keeping distance from the experiences or religiosity in general (items 1, 3, 5, and 7 in Table 2). The second factor (Eigenvalue 1.3) referred to an interpretation that accepted both explanations simultaneously or at least expressed more ambiguity toward the experiences (items 2, 4, and 6 in Table 2).

Associations between types of explanations, religious variables, and diagnosis.

Table 4 presents the results of the associations between various explanations of religious and spiritual experiences and religious self-definition, religious practice, and intrinsic religiosity 
Table 1 Sample religious characteristics of a Dutch bipolar outpatient department

\begin{tabular}{|c|c|c|}
\hline & & Sample \\
\hline \multirow[t]{5}{*}{ Self-definition } & & $n=179$ \\
\hline & Religious nor spiritual & $28 \%$ \\
\hline & Only religious & $9 \%$ \\
\hline & Only spiritual & $28 \%$ \\
\hline & Religious and spiritual & $35 \%$ \\
\hline \multirow[t]{6}{*}{ Original religious affiliation } & & $n=181$ \\
\hline & Roman Catholic & $34 \%$ \\
\hline & Protestant & $30 \%$ \\
\hline & Other or unclear affiliation & $3 \%$ \\
\hline & Islam & $4 \%$ \\
\hline & No affiliation & $29 \%$ \\
\hline \multirow{7}{*}{ Present religious affiliation } & & $n=195$ \\
\hline & Roman Catholic & $19 \%$ \\
\hline & Protestant & $20 \%$ \\
\hline & Other Christian & $1 \%$ \\
\hline & Islam & $3 \%$ \\
\hline & Other & $5 \%$ \\
\hline & No affiliation & $52 \%$ \\
\hline & & $n=179$ \\
\hline \multirow{6}{*}{ DUREL } & 1. Private practice daily & $28 \%$ \\
\hline & Mean (range 1-6) & $2.8 \mathrm{SD} 1.9$ \\
\hline & 2. Public practice $\geq$ weekly & $16 \%$ \\
\hline & $\geq$ monthly & $26 \%$ \\
\hline & Mean (range 1-6) & $2.5 \mathrm{SD} 1.6$ \\
\hline & Intrinsic religiosity summated Mean (range 1-6) & $2.8 \mathrm{SD} .93$ \\
\hline RCOPE Pos., summated & Mean (range 1-4) & $1.8 \mathrm{SD} .77$ \\
\hline RCOPE Neg., summated & Mean (range 1-4) & $1.3 \mathrm{SD} .49$ \\
\hline
\end{tabular}

DUREL Duke University Religion Index, RCOPE Brief Religious Coping Questionnaire. Only present religious affiliation was included in the short version of the questionnaire

(DUREL) and positive and negative religious coping (RCOPE). The most pronounced association was found for positive religious coping in relation to the explanation 'spiritual development' $(\mathrm{r}=.55)$. The 'religious and spiritual' self-definition group and all other religious variables were significantly positively related to the explanation 'spiritual development.' The 'neither religious nor spiritual' selfdefinition group was significantly negatively related to this type of explanation. The 'religious and

Table 2 Frequencies of types of explanations of religious and spiritual experiences during illness episodes of bipolar disorder in a Dutch bipolar outpatient sample

\begin{tabular}{|c|c|c|c|c|}
\hline Type of Interpretation & $\mathrm{n}^{1}$ & $\begin{array}{l}\text { Yes } \\
\%\end{array}$ & $\begin{array}{l}\text { No } \\
\%\end{array}$ & $\begin{array}{l}\text { Don’t } \\
\text { Know \% }\end{array}$ \\
\hline 1. They belong to my spiritual development, have deepened my faith & 125 & 46 & 38 & 16 \\
\hline 2. Such experiences have both religious/spiritual and pathological ('ill') features & 124 & 42 & 33 & 25 \\
\hline 3. I keep my distance from such experiences & 121 & 31 & 53 & 16 \\
\hline $\begin{array}{l}\text { 4. I am not sure whether they are authentic ('real') religious experiences or } \\
\text { belong to bipolar disorder }\end{array}$ & 125 & 30 & 53 & 17 \\
\hline 5. Such experiences belong exclusively to my illness & 123 & 15 & 63 & 22 \\
\hline 6. Such experiences are in fact a sign of spiritual crisis or crisis of faith & 124 & 10 & 70 & 20 \\
\hline $\begin{array}{l}\text { 7. It is better for me to keep distance from faith or spirituality altogether because } \\
\text { such experiences originate from my illness }\end{array}$ & 124 & 4 & 81 & 15 \\
\hline
\end{tabular}

${ }^{1}$ Includes participants who reported they had had religious or spiritual experiences during illness episodes 
Table 3 Factor analysis of types of interpretation of religious and spiritual experiences in a Dutch outpatient sample with bipolar disorder

Rotated Component Matrix

\begin{tabular}{lll}
\hline & Component \\
\cline { 2 - 3 } & 1 & 2 \\
\hline 1. Spiritual development & -.75 & .31 \\
2.Uncertainty about significance & .35 & .60 \\
3. Distance toward experiences & .78 & .19 \\
4. Both spiritual and pathological & -.03 & .76 \\
5. Only pathological & .77 & -.01 \\
6. Spiritual crisis & -.06 & .69 \\
7. Distance from religiosity in general because of the experiences & .54 & .33 \\
\hline
\end{tabular}

Note. Extraction method: principal component analysis. Rotation method: varimax with Kaiser normalization (rotation converged in three iterations)

spiritual' self-definition group and all other religious variables except for negative religious coping were significantly negatively related to the explanation 'only pathological.' No significant associations were found in the chi-square analyses of various types of explanation across BD I and II (results not shown).

\section{Communication About Religious Experiences and Treatment Expectations}

Participants who had had religious experiences communicated with friends (53\%) and family $(51 \%)$ and with professionals in mental health care: psychiatrists (30\%), psychologists $(24 \%)$, nurses or case managers $(18 \%)$, or other professionals $(6 \%)$. Communication with other patients $(14 \%)$, clergy $(12 \%)$, hospital chaplains $(6 \%)$, and alternative therapists $(6 \%)$ was limited, and $6 \%$ communicated with no one about their experiences. Looking at different groups the participants communicated with, it was found that $71 \%$ spoke about their religious experiences in the private sphere, $48 \%$ with a mental health professional, and $16 \%$ with clergy (in or outside the hospital).

Secondly, we explored treatment expectations. Of the total sample, $50 \%$ of the participants considered it very or somewhat important to address religiosity in treatment. This was $60 \%$ for the group with religious experiences and $29 \%$ for the group without such experiences. Of the participants who had had religious experiences, $56 \%$ considered it very or somewhat important to discuss such experiences in treatment.

\section{Discussion}

The current study aimed at describing the prevalence of types of explanations of religious experiences in BD in an outpatient sample and the association of these explanations with religious variables. It explored who patients communicate with about such experiences and their treatment expectations in regard to religiosity.

In the current study, almost half of the participants considered the religious experiences they had had during illness episodes as part of their spiritual development. The view that such experiences have both religious and pathological features was advocated by almost half of the 


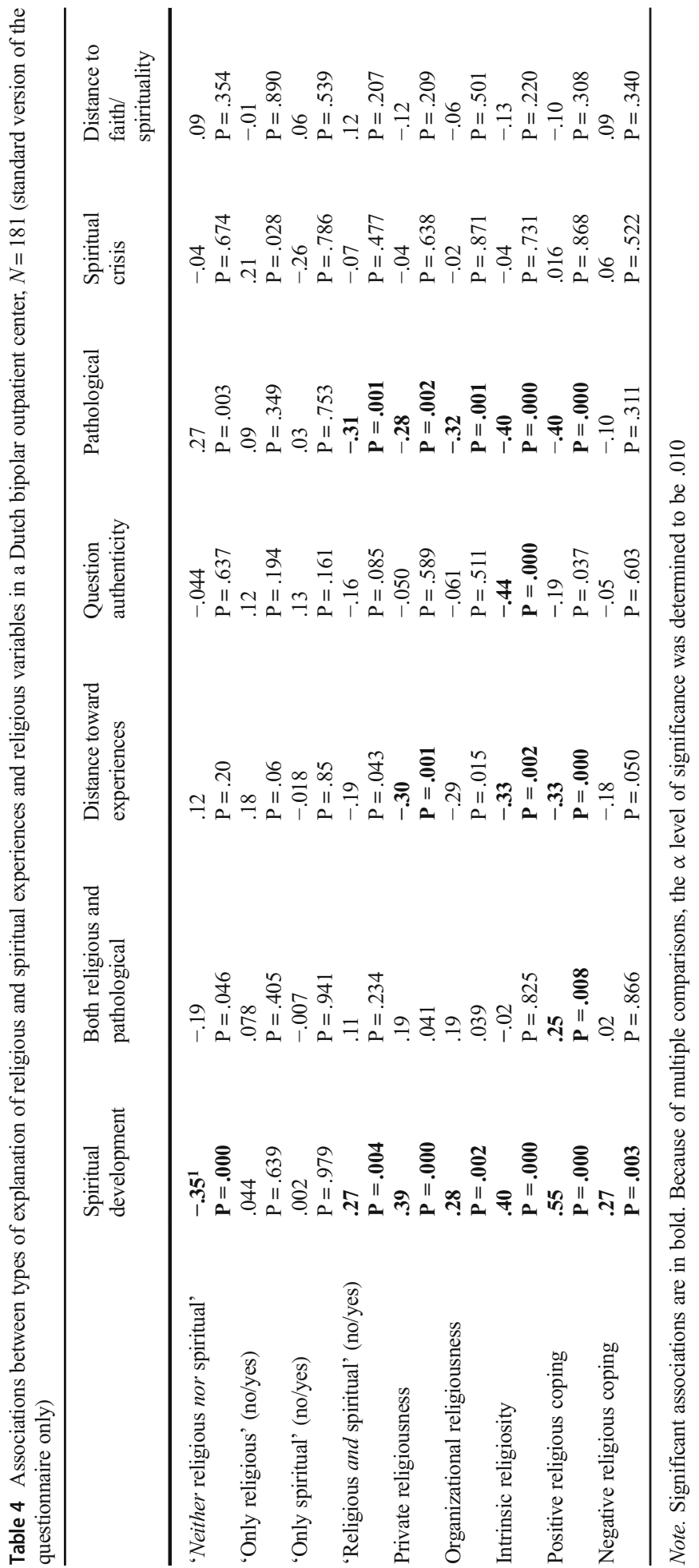


sample as well. In particular, higher scores on positive religious coping as well as on religious practice and intrinsic religiosity were significantly associated with the view that religious experiences in illness episodes were part of participants' spiritual development or of deepening faith. On the other hand, religious variables were inversely related to the view that the experiences were only pathological and should be avoided. The findings in the current study suggest the hypothesis that religious practice, intrinsic religiosity, and positive religious coping may help people to integrate destabilizing experiences related to BD into their life story and spiritual development. However, about one-third of participants with religious experiences kept their distance from such experiences or were uncertain whether they were authentic or belonged to $\mathrm{BD}$.

Huguelet et al. (2016) assessed the subjective importance of religion and spirituality and found a much higher prevalence of what they called 'essential spirituality' in the patient group with a diagnosis of schizophrenia (41\%) compared to BD (6\%). Measured in their study was religious affiliation, private/public practice, importance in daily life, and religion or spirituality as a provider of meaning to life. Huguelet and colleagues explain the differences in outcomes for schizophrenia and $\mathrm{BD}$ by mood swings, characteristic of BD. Although measured differently, the findings of the current study suggest a higher subjective importance of religiosity for patients with $\mathrm{BD}$ compared to the aforementioned study. Huguelet et al. (2010) reported a positive association of religious explanatory models for illness experiences with the importance of the subjective dimension of religion for persons with schizophrenia or schizoaffective disorder. This was the same result as in our study for BD.

The ambiguity regarding strong religious involvement due to its relation with mood swings and development of $\mathrm{BD}$ over time may be the reason for uncertainty and keeping distance from the experiences for about one-third of the sample in the current study. The explorative factor analysis of the various types of interpretation point to a factor implying a view of religious experiences as pathological (versus spiritual) and a second factor implying an interpretation accepting both explanations simultaneously or at least having more ambiguity toward the experiences. These findings call for careful exploration in clinical practice of the various aspects of religiosity and their impact on people's lives.

Of the participants with religious experiences, $71 \%$ shared them in the private environment and almost half shared them with mental health professionals. Of the total sample, $50 \%$ viewed religiosity in general as an important topic to address in treatment. In a qualitative study preceding the current one (Ouwehand et al. 2019b), it was found that not all participants expected mental health care professionals to be equipped to address the issue. To find significance for their often impressive religious experiences, participants sought alternative (spiritual) therapy and training and literature on the Internet, along with standard treatment. These religious or spiritual explanatory models for religious experiences often address existential questions and questions about the meaning of the illness due to their more holistic approach toward healing compared to regular mental health care (Hoffer 2012). Hoenders et al. (2006) reported that $42 \%$ of the patients of a Dutch outpatient center for mental health used complementary or alternative medicine. Kilbourne et al. (2007) described a wide range of usage of alternative healing approaches in an American sample with bipolar disorder, including prayer/spiritual healing (54\%), and meditation/relaxation exercises (53\%).

The literature confirms our finding that a number of the patients considered religiosity as relevant to their mental health problems and treatment (Baetz et al. 2004; Fitchett et al. 1997; Pieper and Van Uden 2005). In the study by Brett (2010) of 'anomalous experiences' in diagnosed and undiagnosed groups, it was found that perceived social support was one of the 
protective factors against experienced distress and that it contributed to a benign outcome. Pieper and Van Uden (2005) reported that only one-quarter of Dutch outpatients with mental health problems judged a parish priest or minister more capable of dealing with problems that were related to religion or worldview compared to mental health professionals. In the current study, $12 \%$ of the participating outpatients with religious experiences had actually communicated with clergy in a parish or congregation. This is in line with broader secularizing tendencies toward the decreasing importance of institutional religion.

In view of the finding that mental health professionals are important communicating partners for at least half of the patients with respect to religious experiences and religiosity in general, the topic deserves more attention in clinical education. This conclusion is in line with the resolution on religious, religion-based, and/or religion-derived prejudice adopted by the American Psychological Association in 2008 and with the World Psychiatric Association position statement on religion and spirituality in 2017. However, the debate on ethical challenges to implement these position statements in clinical practice and the development of professional competencies and guidelines are still in the initial phase (Braam 2017; Gonsiorek et al. 2009; Vogel et al. 2013).

High religious involvement in serious mental illness could be a sign of religious coping. In a Canadian study (Baetz et al. 2006), it was found that higher scores on spiritual values (e.g., search for meaning, giving strength, understanding life's difficulties) were associated with higher odds of having current and past depression and mania. The explanation of Baetz and colleagues for this finding was that the association might reflect the use of religious coping when faced with life difficulties such as mental disorders. Mohr et al. (2006) reported religious coping as a specific way to deal with delusions and hallucinations in $11 \%$ of the participants with schizophrenia in their study. It also could be argued that, in a broad sense, religious language provides more appropriate expression options for psychotic experiences than medical language and that religion offers explanatory models that enhance the patient's value as a human being and their perspective on a hopeful future.

In the sample of this study, 63\% considered themselves as 'only spiritual' or 'religious and spiritual' versus $31 \%$ in the general population (Bernts and Berghuijs 2016). The high involvement in religiosity in the current study can be due to self-selection bias (more religiously interested participants applying than agnostics or atheists). Another explanation could be that high involvement in religiosity is a consequence of the experiences participants had had, especially during mania, which could lead to a religious quest for their significance (Ouwehand et al. 2019b) and therefore to more religious involvement. Especially in forms of new spirituality, 'spiritual experiences' and 'spiritual growth' are important issues (De Hart 2011; Heelas et al. 2005) and might provide explanatory models for the religious experiences related to $\mathrm{BD}$.

\section{Conclusions}

Almost half of the persons with religious experiences in the current study viewed these experiences as part of their spiritual development or as both pathological and spiritual. Uncertainty and distancing from the experiences was present in about one-third of this group and point to ambiguity about the experiences, possibly due to their relation with mood swings. Positive religious coping and religious salience were positively associated with the view that religious experiences related to illness episodes in BD are part of spiritual development or 
deepening of faith and were negatively associated with the view that such experiences should be seen as only pathological. Levels of religiousness of persons with BD were higher than in the general population and may be a consequence of the search for significance of religious experiences related to mania but could also be a sign of religious coping with the illness. Findings of the current explorative study may contribute to further hypothesis-building concerning the direction of the relation between religious explanatory models for illnessrelated experiences and various aspects of religion. Religiosity is viewed as an important topic in treatment by half of the patients with bipolar disorder. In-depth exploration of various religious aspects and their impact on patients' lives is advisable in clinical treatment.

\section{Limitations}

An effort was made to include as many participants as possible, especially persons who had little or no affinity with religiosity and religious experiences. However, the high level of religious involvement of participants in the study may be a sign of self-selection bias; the actual percentage of persons with religious or spiritual experiences may be lower than estimated in the current study $(66 \%)$. However, this limitation pertains less to the analyses of the explanatory models of religious and spiritual experiences because the items assessing them were only filled out by participants who reported having had religious experiences.

The current sample was not entirely representative of the Dutch population with regard to religious affiliation. Only a few strictly orthodox and evangelical Christians were part of the sample, and none or only a very few people were from ethnic minorities. Those groups are difficult to engage in research (King et al. 2006), and they are probably also underrepresented in the specialist outpatient center for BD of the present study.

Explanations of psychotic experiences are transient over time (Huguelet et al. 2010; Larsen 2004) and in the case of $\mathrm{BD}$ are related to mood swings and development of the illness (Ouwehand et al. 2019a). The findings in the current study are a reflection of participants' explanations at a certain point in time and should be interpreted in the context of an ongoing interpretation process.

The low scores on the Brief RCOPE in Dutch studies (Braam et al. 2010; Körver 2013; and the current study) indicate that the items of the RCOPE do not fit the present religious selfunderstanding in a secularized society. In a Danish study $(n=1800)$, between $71 \%$ and $98 \%$ of respondents stated that they did not use the coping strategies of the Brief RCOPE at all in crisis situations. (Hvidtjørn et al. 2014). We obviated this limitation by using various religious measures to give an indication of the religiousness of the sample.

Acknowledgments We would like to thank the staff of the Altrecht Bipolar Department of Altrecht Mental Health Care for their participation in and support of the project and Hetty Vonk for her help with the English version of the manuscript.

Funding The study was financially supported by the Stichting tot Steun VCVGZ, a foundation in the Netherlands that supports innovative projects and research in mental health care, and by the Han Gerlach foundation, a foundation which supports theological education and research.

\section{Compliance with ethical standards}

Conflict of interest The authors of this paper have no conflicts of interest to declare. 


\section{Appendices}

\section{Appendix 1: Questions About Religious and Spiritual Experiences (Ouwehand et al. 2019a)}

Have you ever had...

1. An intense experience of happiness, love, peace, beauty, or freedom?

2. An experience of meaningful synchronicity? An experience of extraordinary meaning in everything, an experience that everything has a special value. Nothing is coincidental. Everything you see or experience seems meaningfully synchronous?

3. An intense experience of unity in your life?

4. The feeling of having a mission in or for the world?

5. An intense experience of the presence of the Divine, of God, or Light?

6. Have you ever experienced a period in which spirituality or faith was completely absent?

7. Have you ever had a sudden profound spiritual insight or a sudden revelation or a vision?

8. Have you ever experienced a period of complete absence of the Divine, God, or Light?

9. Have you ever seen a religious or spiritual apparition?

9a. Of whom? (More answers possible)

A benevolent spiritual being

An evil spiritual being

10. The feeling of being an important religious person?

11. Have you ever heard a divine voice speaking to you?

11a. Of whom? (More answers possible)

A benevolent spiritual being

An evil spiritual being

12. Have you ever had any other religious or spiritual experiences than those mentioned above?

Could you describe this experience?

\section{Appendix 2: Items of the DUREL (Koenig and Büssing 2010)}

\section{DUREL Koenig and Büssing 2010, English}

1 How often do you attend church or other religious meetings? ${ }^{1}$
How often do you spend time in private religious activities, such as prayer, meditation, or Bible study? ${ }^{2}$

In my life, I experience the presence of the Divine (i.e., God).

My religious beliefs are what really lie behind my whole approach to life. ${ }^{3}$

I try hard to carry my religion ${ }^{4}$ into all other aspects of my life.
Current study, Dutch

Hoe vaak gaat $\mathrm{u}$ naar de kerk of andere religieuze/spirituele bijeenkomsten (bijv. voor een dienst, gesprek, meditatie of gebed)?

Hoe vaak besteedt u tijd aan religieuze/spirituele privé activiteiten, zoals bidden, meditatie of studie?

Ik ervaar de aanwezigheid van God/het heilige in mijn leven.

Mijn geloof/levensbeschouwing is wat werkelijk ten grondslag ligt aan mijn hele levenshouding.

Ik doe mijn best om mijn geloof/levensbeschouwing mee te dragen in alle andere aspecten van mijn leven.

\footnotetext{
${ }^{1}$ Spiritual was added (religious/spiritual meetings), and an example was given of such meetings (for example, for a service or for conversation, meditation, or prayer)

2 The word 'Bible' was left out due to the pluralistic religious context of the study. This question was posed before the question on public attendance because public attendance is lower than private religious practice in the Netherlands

${ }^{3}$ The following text was used: My faith/philosophy of life is truly that which lies at the basis of my whole attitude toward life

4 'Faith/philosophy of life' was used instead of 'religion'
} 
Open Access This article is licensed under a Creative Commons Attribution 4.0 International License, which permits use, sharing, adaptation, distribution and reproduction in any medium or format, as long as you give appropriate credit to the original author(s) and the source, provide a link to the Creative Commons licence, and indicate if changes were made. The images or other third party material in this article are included in the article's Creative Commons licence, unless indicated otherwise in a credit line to the material. If material is not included in the article's Creative Commons licence and your intended use is not permitted by statutory regulation or exceeds the permitted use, you will need to obtain permission directly from the copyright holder. To view a copy of this licence, visit http://creativecommons.org/licenses/by/4.0/.

\section{References}

Abdel Gawad, N., Chotalia, J., Parsaik, A., Pigott, T., \& Allen, M. (2017). Religiosity in acute psychiatric inpatients. The Journal of Nervous and Mental Disease, 205(6), 448-452.

American Psychiatric Association. (2013). Diagnostic and statistical manual of mental disorder (5th ed.). Washington, DC: Author.

Azorin, J.-M., Kladjian, A., Fakra, E., Adida, A., Belzeaux, R., \& Hantouche, S. (2013). Religious involvement in major depression: Protective or risky behavior? The relevance of bipolar spectrum. Journal of Affective Disorders, 150(20), 753-759.

Baetz, M., Bowen, R., Jones, G., \& Koru-Sengul, T. (2006). How spiritual values and worship attendance relate to psychiatric disorders in the Canadian population. Canadian Journal for Psychiatry, 51, 654-661. https://www.ncbi.nlm.nih.gov/pubmed/17052033.

Baetz, M., Griffin, R., Bowen, R., \& Marcoux, G. (2004). Spirituality and psychiatry in Canada: Psychiatric practice compared with patient expectations. Canadian Journal of Psychiatry, 49(4), 265-271.

Barker, E. (2008). The church without and the God within: Religiosity and/or spirituality? In E. Barker (Ed.), The centrality of religion in social life. Hampshire: Ashgate.

Bassett, A. M., Baker, C., \& Cross, S. (2015). Religion, 'normative uncertainty' and clinical assessments. Journal of Psychiatric and Mental Health Nursing, 22, 606-615.

Berghuijs, J., Pieper, J., \& Bakker, C. (2013). Being 'spiritual' and being 'religious'. Journal of Contemporary Religion, 18(1), 15-32.

Bernts, T., \& Berghuijs, J. (2016). God in Nederland [God in the Netherlands 1966-2015] [God in the Netherlands 1966-2015]. Utrecht: Ten Have.

Braam, A. W. (2017). Towards a multidisciplinary guideline religiousness, spirituality, and psychiatry: What do we need? Mental Health, Religion \& Culture, 20(6), 579-588.

Braam, A. W., Schrier, A. C., Tuinebreijer, W. C., Beekman, A. T. F., Dekker, J. J. M., \& De Wit, M. A. S. (2010). Religious coping and depression in multicultural Amsterdam: A comparison between native Dutch citizens and Turkish, Moroccan and Surinamese/Antillean migrants. Journal of Affective Disorders, 125, $269-278$.

Brett, C. (2010). Transformative crises. In I. Clarke (Ed.), Psychosis and spirituality: Consolidating the new paradigm (pp. 155-175). Chichester: Wiley.

Casey, P. (2013). I'm spiritual but not religious' - Implications for research and practice. In C. C. H. Cook (Ed.), Spirituality, theology, and mental health (pp. 20-40). London: SCM Press.

De Hart, J. (2011). Zwevende gelovigen: Oude en nieuwe spiritualiteit [The floating faithful: Old and new spirituality]. Amsterdam: Uitgeverij Bert Bakker.

Fitchett, G., Burton, L. A., \& Sivan, A. B. (1997). The religious needs and resources of psychiatric inpatients. Journal of Nervous and Mental Disease, 85, 320-326.

Fulford, K. W. M. B., \& Sadler, J. Z. (2011). Mapping the logical geography of delusion and spiritual experience: A linguistic-analytic research agenda covering problems, methods, and outputs. In J. R. Peteet, F. G. Lu, \& W. E. Narrow (Eds.), Religious and spiritual issues in psychiatric diagnosis. A research agenda for DSM-V (pp. 229-258). Washington, DC: American Psychiatric Association.

Gallemore, J. L., Jr., Wilson, W. P., \& Rhoads, J. (1969). The religious life of patients with affective disorders. Diseases of the Nervous System, 30(7), 483-487.

Geertz, C. (1973). The interpretation of cultures. New York: Basic Books.

Getz, G. E., Fleck, D. E., \& Strakowski, S. M. (2001). Frequency and severity of religious delusions in Christian patients with psychosis. Psychiatry Research, 103(1), 87-91.

Gonsiorek, J. C., Richards, P. S., Pargament, K. I., \& McMinn, M. R. (2009). Ethical challenges and opportunities at the edge: Incorporating spirituality and religion into psychotherapy. Professional Psychology: Research and Practice, 40, 385-395. 
Heelas, P., Woodhead, L., Seel, B., Tusting, K., \& Szerszynski, B. (2005). The spiritual revolution: Why religion is giving way to spirituality. Oxford: Blackwell.

Helman, C. G. (2001). Culture, health and illness. Boca Raton: CRC Press.

Hoenders, H. J. R., Appelo, M. T., \& Milders, C. F. A. (2006). Complementaire en alternatieve geneeswijzen (CAG) en psychiatrie: Meningen van patiënten en psychiaters. [Complementary and alernative medicine (CAG) and psychiatry. Opinions of patients and psychiatrists]. Tijdschrift voor Psychiatrie [Journal of Psychiatry], 48, 733-737.

Hoffer, C. (2012) Fenomenologisch geïnspireerd onderzoek naar religieuze geneeswijzen en de betekenis daarvan voor de ggz [Phenomenology-inspired research into religious healing and the significance thereof for mental health care]. In P. J. Verhagen \& H. J. G. M. van Megen (Eds.), Handboek Psychiatrie, religie en spiritualiteit [Manual on psychiatry, religion and spirituality]. Utrecht: de Tijdstroom.

Hoffer, C., \& Hoenders, R. (2010). Complementaire, alternatieve en religieuze geneeswijzen [Complementary, alternative and religious medicine]. In J. De Jong \& S. Colijn (Eds.), Handboek Culturele psychiatrie en psychotherapie [Handbook on cultural psychiatry and psychotherapy] (pp. 451-469). Utrecht: de Tijdstroom.

Huguelet, P., Mohr, S., Gilliéron, C., Brandt, P.-Y., \& Borras, L. (2010). Religious explanatory models in patients with psychosis: A three-year follow-up study. Psychopathology, 43(4), 230-239.

Huguelet, P., Mohr, S., Bétrisey, C., Borras, L., Gillieron, C., Marie, A. M., Rieben, I., Perroud, N., \& Brandt, P. Y. (2011). A randomized trial of spiritual assessment of outpatients with schizophrenia: Patients' and clinicians' experience. Psychiatric Services, 62(1), 79-86.

Huguelet, P., Mohr, S. M., Olié, E., Vidal, S., Hasler, R., Prada, P., Bancila, M., Courtet, P., Guillaume, S., \& Perroud, N. (2016). Spiritual meaning in life and values in patients with severe mental disorders. The Journal of Nervous and Mental Disease, 204(6), 409-414.

Hvidtjørn, D., Hjelmborg, J., Skytthe, A., Christensen, K., \& Hvidt, N. C. (2014). Religiousness and religious coping in a secular society: The gender perspective. Journal of Religion and Health, 53(5), 1329-1341.

Kilbourne, A. M., Copeland, L. A., Zeber, J. E., Bauer, M. S., Lasky, E., \& Good, C. B. (2007). Determinants of complementary and alternative medicine use by patients with bipolar disorder. Psychopharmacology Bulletin, 40(3), 104-115.

King, M., Weich, S., Nazroo, J., Blizard, B., \& On Behalf of the Empiric Team. (2006). Religion, mental health and ethnicity: EMPIRIC-A national survey of England. Journal of Mental Health, 15(2), 153-162.

Kleinman, A. (1988). The illness narratives. New York: Basic Books.

Koenig, H. G. (2009). Research on religion, spirituality, and mental health: A review. The Canadian Journal of Psychiatry, 54(5), 283-291.

Koenig, H. G., \& Büssing, A. (2010). The Duke University Religion Index (DUREL): A five-item measure for use in epidemiological studies. Religions, 1, 78-85.

Körver, J. W. G. (2013). Spirituele coping bij longkankerpatiënten [Spiritual coping in patients with lung cancer]. Thorn: Schrijen-Lippertz.

Kroll, J., \& Sheehan, W. (1989). Religious beliefs and practices among 52 psychiatric inpatients in Minnesota. American Journal of Psychiatry, 146(1), 67-72.

Larsen, J. A. (2004). Finding meaning in first episode psychosis: Experience, agency, and the cultural repertoire. Medical Anthropology Quarterly, 18(4), 405-523.

Lipka, M., \& Gecewicz, C. (2017, September 6). More Americans now say they are spiritual but not religious. Pew Research Center. https://www.pewresearch.org/fact-tank/2017/09/06/more-americans-now-say-theyrespiritual-but-not-religious/. Accessed 28 Sept 2018.

Michalak, E. E., Yatham, L. N., Kolesar, S., \& Lam, R. W. (2006). Bipolar disorder and quality of life: A patientcentered perspective. Quality of Life Research, 15(1), 25-37.

Mitchell, L., \& Romans, S. (2003). Spiritual beliefs in bipolar affective disorder: Their relevance for illness management. Journal of Affective Disorders, 75(3), 247-257.

Mizuno, Y., Hofer, A., Frajo-Apor, B., Wartelsteiner, F., Kemmler, G., Pardeller, S., Suzuki, T., Mimura, M., Fleischhacker, W. W., \& Uchida, H. (2018). Religiosity and psychological resilience in patients with schizophrenia and bipolar disorder: An international cross-sectional study. Acta Psychiatrica Scandinavica, 137, 316-327.

Mohr, S., Brandt, P., Borras, L., Gilliéron, C., \& Huguelet, P. (2006). Toward an integration of spirituality and religiousness into the psychosocial dimension of schizophrenia. American Journal of Psychiatry, 163, 19521959.

Mohr, S., Borras, L., Nolan, J., Gilliéron, C., Brandt, P., Eytan, A., Leclerc, C., Perroud, N., Whetten, K., Pieper, C., Koenig, H. G., \& Huguelet, P. (2012). Spirituality and religion in outpatients with schizophrenia: A multi-site comparative study of Switzerland, Canada, and the United States. International Journal of Psychiatry in Medicine, 44(1), 29-52. 
Muthert, J. K. (2007). Verlies en verlangen: Verliesverwerking bij schizofrenie [Loss and longing: Dealing with loss in schizophrenia]. Assen: Van Gorcum.

Ouwehand, E., Muthert, J. K., Zock, T. H., Boeije, H., \& Braam, A. W. (2018). Sweet delight and endless night: A qualitative exploration of ordinary and extraordinary religious and spiritual experiences in bipolar disorder. The International Journal for the Psychology of Religion, 28(1), 31-54.

Ouwehand, E., Braam, A. W., Renes, J. W., Muthert, J. K., Stolp, H. A., Garritsen, H. H., \& Zock, T. H. (2019a). Prevalence of religious and spiritual experiences and the perceived influence thereof in patients with bipolar disorder in a Dutch specialist outpatient center. The Journal of Nervous and Mental Disease, 207(4), 291299.

Ouwehand, E., Zock, T. H., Muthert, J. K., Boeije, H., \& Braam, A. W. (2019b). "The Awful Rowing toward God": Interpretation of religious experiences by individuals with bipolar disorder. Pastoral Psychology, 68(4), 437-462.

Pargament, K. I. (1999). Religious/spiritual coping. In Fetzer Institute \& National Institute on Aging Working Group (Eds.), Multidimensional measurement of religiousness/spirituality for use in health research (pp. 4356). Kalamazoo: Fetzer Institute.

Pieper, J., \& van Uden, M. (2005). Religion and coping in mental health care. Amsterdam: Rodopi.

Possamai, A. (2005). In search of new age spiritualities. Bodmin: MPG Books.

Spearing, M. K., Post, R. M., Leverich, G. S., Brandt, D., \& Nolen, W. (1997). Modification of the Clinical Global Impressons (CGI) Scale for use in bipolar illness (BP): The CGI BP. Psychiatric Research, 73, 159171.

Streib, H., \& Hood, R. W. (2016). Understanding “spirituality"-Conceptual considerations. In H. Streib \& R. W. Hood (Eds.), Semantics and psychology of spirituality: A cross-cultural analysis (pp. 3-19). Cham: Springer.

Stroppa, A., \& Moreira-Almeida, A. (2013). Religiosity, mood symptoms and quality of life in bipolar disorder. Bipolar Disorders, 15, 385-393. https://doi.org/10.1111/bdi.12069.

Stroppa, A., Colugnati, F. A., Koenig, H. G., \& Moreira-Almeida, A. (2018). Religiosity depression and quality of life in bipolar disorder: A two-year prospective study. Revista Brasileira de Psiquiatria, 40(3), $238-243$.

Taves, A. (2009). Religious experience reconsidered: A building-block approach to the study of religion and other special things. Princeton: Princeton University Press.

Tepper, L., Rogers, S. A., Coleman, E. M., \& Malony, H. N. (2001). The prevalence of religious coping among persons with persistent mental illness. Psychiatric Services, 52(5), 660-665.

Van de Donk, W., \& Plum, R. (2006). Begripsverkenning. [Exploration of concepts]. In W. B. H. J. Van De Donk, A. P. Jonkers, G. J. Kronjee, \& R. J. J. M. Plum (Eds.), Geloven in het publieke domein: Verkenningen van een dubbele transformatie [Faith in the public domain: Explorations of a dual transformation] (pp. 171195). Amsterdam: Amsterdam University Press.

Vogel, M. J., McMinn, M. R., Peterson, M. A., \& Gathercoal, K. A. (2013). Examining religion and spirituality as diversity training: A multidimensional look at training in the American Psychological Association. Professional Psychology: Research and Practice, 44(3), 158-167.

Zuidgeest, P. (2001). The absence of God: Exploring the Christian tradition in a situation of mourning. Leiden: Brill.

Publisher's Note Springer Nature remains neutral with regard to jurisdictional claims in published maps and institutional affiliations.

\section{Affiliations}

\section{Eva Ouwehand ${ }^{1,2} \cdot$ Arjan W. Braam $^{3,4}$ - Joannes W. Renes ${ }^{5} \cdot$ Hanneke J. K. Muthert $^{2}$. Hetty T. Zock ${ }^{2}$}

1 Altrecht Expertisegroep Zingeving, Vrijbaan 2, 3705 WCZeist, The Netherlands

2 Faculty of Theology and Religious Studies, University of Groningen, Groningen, The Netherlands

3 University of Humanistic Studies, Utrecht, The Netherlands

4 Department of Acute Psychiatry and Department of Residency Training, Altrecht Mental Health Care, Utrecht, The Netherlands

5 Altrecht Mental Health Care, Altrecht Bipolair, Utrecht, The Netherlands 